\title{
Donation and transplantation of allogeneic hematopoietic stem cells
}

\author{
Ilana Kopolovic MD, Robert Turner MD
}

\begin{abstract}
About 800 Canadians are waiting for an allogeneic stem cell transplant, and fewer than half of the searches for donors in Canada successfully find a match
\end{abstract}

Only $30 \%$ of patients with indications for a transplant have a matched related donor; the remaining $70 \%$ seek an unrelated donor on the world's registry. Nonwhite Canadians have a particularly low likelihood of finding a match. ${ }^{1,2}$ Appendix 1 lists common indications for transplant (available at www .cmaj.ca/lookup/suppl/doi:10.1503 /cmaj.101866/-/DC1).
Fewer than $1 \%$ of Canadians are listed in the stem cell registry

Canada falls behind 11 leading countries, with only 77 donors per 10000 citizens. ${ }^{4}$ Last year, about 300 Canadians received donations of stem cells; only 100 Canadians donated. About $80 \%$ of stem cells transplanted in Canada are imported, considerably more than in most other countries.
Unlike solid organs or blood, the matching criteria for the transplantation of allogeneic stem cells require a high degree of compatibility between human leukocyte antigen phenotypes

The large degree of genetic variability among histocompatible leukocyte antigens, combined with Canada's ethnically diverse population, demands a large registry that includes donors from various backgrounds. Currently, Bone Marrow Donors Worldwide amalgamates 66 registries from 47 countries and includes over 17 million donors. ${ }^{3}$

\section{People can join the Canadian donor registry from home}

Canadians can join the registry on the website of Canadian Blood Services. ${ }^{5}$ A buccal swab, used to type potential donors, can then be sent by mail. Of 237000 donors listed in the registry, about 100 are asked to donate each year. However, when a donation is requested, that donor may be the only person who can enable the recipient to receive this potentially life-saving therapy.

\footnotetext{
Useful resources

- Canadian Blood Services - One Match Stem Cell and Marrow Network: www.bloodservices.ca/onematch

- Bone Marrow Donors Worldwide: www.bmdw.org
}

There are currently two methods of collecting donor stem cells

Most stem cells are collected from peripheral blood. The donor is given filgrastim before apheresis (i.e., stem cells are extracted from donor blood and the remaining components of the blood are returned to the donor). Transient pain and minor side effects are common. Fewer than $5 \%$ of donors have severe side effects (Appendix 1, available at www .cmaj.ca/lookup/suppl/doi:10.1503 /cmaj.101866/-/DC1). A recent large cohort study reported no lifethreatening events with this procedure. ${ }^{6}$ Harvesting bone marrow is more invasive and involves general anesthetic. A review of 27770 such donations identified 12 severe events, including 4 cardiac events and 1 death by pulmonary embolism.?

For references, please see Appendix 2, available at www.cmaj.ca/lookup/suppl /doi:10.1503/cmaj.101866/-/DC1

Competing interests: Robert Turner has received support from Bristol-Myers Squibb, Novartis, Schering and Ortho Biotech. No other competing interests were declared.

This article has been peer reviewed.

Affiliations: From the Department of Medicine (Kopolovic); the School of Cancer Engineering and Imaging Sciences, and the Department of Haematology and Medical Oncology (Turner), University of Alberta, Edmonton, Alta.

Correspondence to: Dr. Ilana Kopolovic, kopolovi@ualberta.ca

CMAJ 2011. DOI:10.1503/cmaj.101866 